\section{Desafios ao capitalismo *}

Por John G. Gurley. Ed. Brasiliense, $188 p$.

A abordagem dos aspectos mais relevantes da economia contemporânea, a partir de um enfoque nå-convencional, impulsionada, principalmente desde a Guerra do Vietnam, pelos intelectuais e acadêmicos norte-americanos da chamada corrente radical, chega ao nosso país pela tradução de algumas das suas obras mais expressivas.

O lançamento, em 1977, da tradução de The fiscal crisis of the State, de James $\mathrm{O}^{\prime}$ Connor, ${ }^{1}$ originalmente publicado em 1973, veio acentuar, também em nosso meio, a atualidade das controvérsias suscitadas pela nova corrente e a oportunidade de se conhecer o pensamento de outro dos seus mais destacados expoentes, expresso em obra editada na mesma época.

O interesse em torno do economista e professor americano avulta ainda em face de sua curiosa trajetória intelectual: conhecido por análises convencionais e ortodoxas dos fenômenos monetários, fato que caracterizara grande parte de sua vida acadêmica e literária, sentiu-se motivado, no estudo dos sistemas econômicos, a abandonar os métodos ortodoxos e, utilizando-se da teoria e prática de Marx, Lenin e Mao Tsé-Tung, passou a analisar e criticar a política de apoio e respaldo dos governos capitalistas à atuação das grandes cornnrações no comércio mundial e fluxo de capitais internacionais.

Como que assumindo o papel de promotor dentro de um hipotético julgamento da economia do século $X X$, coloca no banco dos réus o sistema capitalista internacional, representado por seu líder, os Estados Unidos da América. Contudo, apesar da sua conversão à corrente radical, o autor não chega a formular um conceito novo.

John Kenneth Galbraith, cristalizando considerações feitas ao longo de trabalhos anteriores, lançou, por sinal também em 1973, a sua obra A economia e o objetivo público, 2 na qual critica o setor das grandes empresas americanas, cujo desenvolvimento estaria gerando graves' desigualdades econômicăs, setoriais e individuais, fenômeno que se localizaria na base das tensões e conflitos sociais, deterioração do meio ambiente e outras significativas distorcões da sociedade moderna, levando-o a cogitar da adoção de um regime neosocialista; este, com a neutralização do poder das grandes corporações, seus agentes e aliados político-burociáticos, visaria ao fortalecimento geral do setor competitivo, o que, juntamente com outras medidas, permitiria a estabilização das atividades econômicas e a desconcentração do poder

James $O^{\prime}$ Connor, no referido livro, aqui publicado sob o título USA - a crise do estado capitalista, abordou a mesma problemática denunciando a existência de séria e profunda crise em todos os níveis do sistema econômico americano, por força da ação do Estado na assistência ao setor monopolista. Pela análise dos gastos governamentais e receitas públicas, o autor procurou explicar as facetas desse impasse, sugerindo duas alternativas que, na sua opinião, poderiam mostrar-se positivas: o modo de produção socialista ou a adoção do modelo complexo socioindus irial. Neste, o setor monopolista seria levado latraido por incentivos estatais, acompanhados de modificações estruturais substanciais) a desenvolver programas de interesse social. A transferência de grandes volumes de recursos para ou- tras áreas aliviaria os conflitos e tensões devidos às distorções resultantes da crise enfrentada pelo Estado e suportada pela sociedade americana.

Gurley dá a sua contribuição ao debate, focalizando outros aspectos do tema. Sua preocupação transcende o âmbito da situação interna dos EUA, localizando-se, principalmente, no estudo do relacionamento dessa nação, enquanto líder, com o resto do sistema capitalista monopolista mundial e de suas lutas e ingerências (diretas ou indiretas), visando à manutenção da dominação sobre o sistema e, em especial, à expansão das áreas de influência e exploracão econômica, essenciais à sobrevivência do capitalismo no estáaio de desenvolvimento histórico em que se encontra atualmente. Gurley chama a atenção para a evolução dos acontecimentos que deram origem à Guerra do Vietnam, cujos verdadeiros motivos - articulacōes e disputas de interesses econômicos em torno de um espaço geopolítico considerado estratégico parecem-lhe dissımulados pelo véu da defesa e soerguimento de uma sociedade, contra uma ideologia em ameaça de sua liberdade e soberania.

Observa Gurley que o enfraquecimento do capitalismo teria raízes em uma contradição fundamental: por um lado, a ampliação para o exterior das atividades econômicas das grandes empresas condiciona a obtenção dos lucros que, por sua vez, permitem a acumulação da renda e riqueza $\{e$, conseqüentemente, do poder, em mãos de uma minoria privilegiadal, condições essenciais à dinâmica do sistema; por outro, uma série de obstáculos a caracterizarem os desafios colocados em oposição a esse movimento. Para ele, o obstáculo mais importante, ainda que não seja o único, é a escalada da ideologia marxista, viabilizada na organização de muitos países nos últimos 60 anos; as demais barreiras apenas reforçam a tendência à disputa capitalismo/marxismo.

O impasse, para o autor, forçosamente levará a mudanças no sistema capitalista monopólico, já que 
vislumbra remotas possibilidades de sua sobrevivência dentro dos padrões àtuais. Assegura que se torna cada vez mais difícil aos EUA garantir sua liderança e impor seu domínio por meio dos métodos usuais, como a ajuda militar, cultural e financeira. Isso devido a vários movimentos no interior das próprias sociedades capitalistas crescimento da ideologia marxista, ecologistas e protetores do meio ambiente, etc. - além de reações cada vez menos controláveis, principalmente nos países dependentes, ao crescente poder das grandes corporações, incentivadas agora pelas novas opções abertas com a formação do cartel dos países árabes, após a crise do petróleo em 1973

Analisando as perspectivas para o futuro do capitalismo monopóli$\mathrm{co}$, Gurley apresenta prognósticos baseados em duas direções. Partindo do pressuposto de que o impasse criado pela contradição descrita necessariamente afetará o rumo dos acontecimentos, mostra que uma das alternativas é a mudança do modo de produção para o socialismo. Essa alteração poderia acontecer a partir da conscientização, pela maioria desfavorecida, dos privilégios abocanhados pela minoria privilegiada, e de uma nova tomada de posição, em termos de valores éticos e culturais, onde o aprimoramento do homem se tornaria uma realidade em contraste com o culto e exaltação exagerados aos bens puramente materiais e supérfluos, tal como exige a ideologia capitalista. Mas essa saída, por estar ligada a problemas como o da produção coletiva e o da distribuição da riqueza e outras medidas em contraposição aos interesses burguéses, seria certamente difícil a curto prazo, especialmente nos EUA, segundo o autor.

Nesta altura, o: autor, aprofundando-se no seu papel de promotor público, julga-se em condições de formular a sua principal acusação polítjca, ao divisar a conseqüência do impasse numa provável tendência de supressão das liberdades individuais, sacrificadas para assegurar o pre domínio da liberdade de ação do capital; assim, haveria uma profunda alteração no jogo político, com um Estado forte e opressivo a garantir os interesses do capital e da classe que detém sua propriedade. Esse regime, neofascista, baseado no racismo (favorável aos brancos), teria por objetivo a divisão dos trabalhadores e o conseqüente enfraquecimento do confronto capital/trabalho. Nésse contexto, o emprego de forças militares interna externamente daria o toque final à nova feição do sistema politico-econômico-social. Os mecanismos de amparo e sustentaçăo ao desenvolvimento do capitalismo seriam introduzidos artificial e contraditoriamente, reforçando e aprofundando os conflitos e tensões enfrentados pelas sociedades modernas, exigindo, cada vez mais, medidas de repressão.

A promotoria encerra seu trabatho, deixando em aberto essás questões para que os jurados decidam a sorte do réu. Os defensores encontrarão nos argumentos da acusação farto material para alımentar proposições contrárias e críticas aos pontos mais frágeis da análise de Gurley. A corrente favorável, certamente, ampliará e reforçará as teses do autor, apontando as distorções porventura esquecidas ou negligenciadas, adicionando novos e vigorosos ataques ao vilão do século $X X$. A contribuição do livro localiza-se justamente nas possibilidades de alargar e aprofundar os debates em torno da problemática que atinge, principalmente, paises dependentes como o Brasil. Um mérito adicional, a ser creditado ao trabalho desenvolvido por John Gurley, é a exposição clara, didática, acessivel e interessante dos principais pressupostos da teoria marxista, com base nas formulações e experiências dos grandes líderes dessa ideologia - Marx, Lenin e Mao - que ocupa aproximadamente $80 \%$ de sua obra.

\section{Amarilis Maier Sampaio}

- Esta resenha foi realizada sob a orientação acadêmica do Prof. Eurico Korff, a quem agradeço o valioso apoio.
O'Connor, James. USA - a crise do es tado capitalista. Rio de Janeiro, Paz e Terra, 1977. Publicado nos EUA, em 1973, com o titulo The fiscal crisis of the State.

2 Galbrath, John Kenneth A economia e - objetivo público. São Paulo, Martirs, 1975. Publicado nos EUA, em 1973, com o titulo Economics a the public purpose. 